\title{
The Effect of Accrual-GAS on the Financial Reporting Reliability With HR Capacity as Mediating Variables
}

\author{
Mega Kusuma Aryani ${ }^{\bowtie}$, Kiswanto \\ Department of Accounting, Faculty of Economics, Universitas Negeri Semarang, \\ Gedung L2 Lantai 2 Sekaran Gunungpati Semarang 50229, Indonesia \\ DOI: http://dx.doi.org/10.15294/jda.v9i2.9733
}

Received: 19 April 2017. Revised: 27 June 2017. Accepted: 30 August 2017. Published: 31 September 2017

\begin{abstract}
This research aimed to gets empirical evidence of the influence of human resource capacity with relation accrual-based government accounting standards on the relia-bility of financial reporting. This Research is a population research with the number of respondents 52 State Civil Apparatus who officiate as treasurer in each SKPD and employees in the accounting field in BPPKAD Kudus. Analysis method for hypothesis in this research used path analysis. The results of this research indicate that accrual basis government accounting standards and the capacity of human resources has a positive influence to the reliability of financial reporting, while accrual based government accounting standards have a positive effect on the capacity of human resource, but the capacity of human resources is not mediate the influence between accrual based government accounting standards to reliability of financial reporting. Conclusion of this study says that implementation of accrual based in Kudus District can support reliability of financial reporting and the capacity of State Civil Apparatus who officiate as treasurer in each SKPD and employees in the accounting field in BPPKAD Kudus also supports the created of financial reporting reliability.
\end{abstract}

Keywords: Capacity of HR; Reliability; Accrual Based

How to cite (APA 6th Style)

Aryani, M. K. \& Kiswanto. (2017). The Effect of Accrual-GAS on the Financial Reporting Reliability With HR Capacity as Mediating Variables. Jurnal Dinamika Akuntansi, 9(2), 110-122.

\section{INTRODUCTION}

Output of an accounting system is in the form of financial information, be it financial accounting or local government accounting. Financial accounting produces financial information in the form of financial and accounting reports of local governments to produce financial information in the form of local government financial statements. Over time, there has been a growing demand for local government accounting practices and has implications for local government management to be able to present reliable financial statements. As stated by Noviyanti and Kiswanto (2016) that the regional autonomy law gives the authority to the regional administration which is wider, real and responsible and the enactment of regional autonomy has a function so that each region will be more advanced, independent, prosperous and able to implement the local government for the prosperity of the society in that area. The rapid

Mega Kusuma Aryani ( $₫)$

E-mail: kusumamamega@gmail.com 
development of local government accounting and the enactment of regional autonomy lead to greater demands related to public transparency and accountability by public sector institutions such as local governments. The manifestation of transparency and accountability is by creating reliable local government financial statements.

Winidyaningrum, (2009) stated that reliability is the ability of information to give trust that the information is true or valid. The information in the financial statements must be reliable that is free from misleading notions and material errors, present every fact honestly, and could be verified. Diawati (2015) also states that local government financial statement should be presented by a process that gives assurance of reliability in the presentation and can be accounted for and the reporting can be useful in decision-making by the user. Research conducted by Sukirman (2011), Desmiyawati (2014), Sari \& Witono, (2014), Anggraeni, (2015) also use reliability as dependent variable.

The government recognizes that financial reporting that has been set before 2005 has not really represented the true state of the regional finances. This is due to the financial statements made are still based on the cash basis. Winidyaningrum, (2009) also mentions that there are many irregularities that have been found by the Financial Audit Board in the implementation of government financial statement audit. It was due to in the cash base provides a lot of flexibility to commit fraud, whereas on the other hand the local government financial statements have as a means of accountability to the public. Therefore, qualitative characteristics in the presentation of local government financial statements become unfulfilled, in addition there are many irregularities in local government financial reporting.

Surepno, (2015) in his research proposes a similar solution to improve the quality of financial information presentation from local government that is by using Accrual GAS. Accrual GAS is an accounting principle applied in preparing and presenting government financial statements that recognize transactions / events in accordance with their occurrence not when the transactions / events are paid or received. The accrual basis recommended by GR No.71 of 2010 is to recognize income -LO, expenses, assets, liabilities, and equities. The implementation of Accrual GAS according to GR. 71 Year 2010 has been running for six years since published. However, pros and cons are still mostly found mainly related to human resources (HR) that adequate. Human resources are said to be the key to implement accrual GAS thus creating reliable financial statements. In fact, human resources are not yet ready for the full disclosure of accrualbased GAS, so that financial reporting by local government is not reliable.

The implementation of Accrual GAS according to GR. 71 Year 2010 has been running for six years since the issuance, but Surepno (2015) reveals that there are problems that arise on the concerns of local governments are unable to meet the expectations of the central government to present accrual-based financial statements because the implementation of accrual basis in a governmental accounting system of a country is not an easy thing. Research on accrual GAS in Gianyar Bali by Widyastuti et al (2015) also reveals that Gianyar district government is still making preparations in the implementation of Accrual GAS, such as socialization to human resources and who becomes head of finance in SKPD Gianyar District. On the other hand, there is evidence that human resource capacity will affect reliability. Sukirman et al (2011) reveal that the capacity of human resources affects on the reliability of financial reporting in Banyumas Local Government. Winidyaningrum (2009),Sari \& Witono, (2014),Desmiyawati (2014), Anggraeni, (2015) also show similar results in their research that human resource capacity can affect the reliability of financial reporting.

Accrual GAS must be implemented by all government agencies due to it is based on GR. 71 Year 2010. So with the basis of this government regulation, each government financial reporting must be based on Accrual GAS so it can be said that this is forcing. Coercion made by the government against various government agencies has consequences, can be rewards or punishment (sanctions), as is the nature of the law that force. Giving reward or punishment will generate motivation for each agency to make financial statements in accordance with applicable 
standards. This motivation will then affect the performance and attitude of one's behaviour (Wahyuni, 2008); and (Utami, 2012). Possible behaviour appears for employees of government agencies is to improve self-ability to be able to process accounting records into financial statements by referring to Accrual GAS which is different from previous accounting standards applied.

Hence, based on the research gap and gap phenomenon above, this study uses human resource capacity as a mediating variable of influence between Accrual GAS Implementation on Financial Reporting Reliability. As we know that the implementation of accrual basis in the government environment must be supported by adequate human resources. Human resources are also said to be the key to implement accruals GAS thus creating reliable financial statements. Where there are not many studies that try to make the capacity of human resources as a variable in the research model. Capacity of Human resources in this research is defined as the ability of the State Civil Apparatus either in the individual or group level to perform the duties, functions and authorities that have been determined by the government to achieve the goal effectively and efficiently. So it is expected to present the variable of human resources capacity is able to be a solution to the problems encountered in the implementation of Accrual GAS in order to improve the quality of financial reporting. So, the purpose of this study is to find out how big the influence of accrual-based government accounting standards on the reliability of financial reporting on local government with the capacity of human resources as a mediating variable.

Grand theory underlying the relationship between dependent, independent and mediator variables in this research is regulation theory and reinforcement theory. Stigler (1971) states that the theory of regulation is a regulation-related activity that describes the relationship between the political power of the interest group (executive) as the demand / legislative side as supply, besides the regulation theory also believes that certain rules or provisions are required in the process of accounting. The implementation of the regulation used in this study is based on the law that has been issued by the government to set accrual-based government accounting standards and human resource capacity as State Civil Apparatus, such as GR No. 71 of 2010 concerning Accrual Based Government Accounting Standard and Act No. 5 Year 2014 on State Civil Apparatus.

Reinforcement theory speaks of how individual behaviours will be repeated if they have positive consequences and how behaviour will not be repeated if they have negative consequences which means that every action will be repeated and not if there is a reinforcement Robins \& Judge, (2007). The behaviour that is expected to change is the behaviour to always comply with the new standard of government financial reporting. If the agency does not comply, it will always get an opinion other than unqualified. This means a negative stimulus, so that human resources in the institution fight to improve self-capacity to be able to apply the new Accrual GAS.

Based on the gap phenomenon and the researchers' understanding from the theory and several studies, the problem in this study is how the reliability of the government financial statement can be improved. One possible step to improve reliability is the implementation of Accrual GAS. The implementation of this Accrual GAS will be applicable well if supported by human resource capacity. So the implementation of Accrual GAS for government agencies can run well when making financial statements done by human resources that have good capacity. ASN (State Civil Apparatus) is required to enforce regulations on Accrual GAS and is expected to produce reliable financial statements.

The concept of regulatory theories focuses on regulations made by the government to achieve a balance of information for the maker or user of the information itself. In the relationship between accrual GAS and reliability, there are regulations that regulate it which is Government Regulation No. 71 of 2010. Government Regulation No. 71 presents the regulation related to the implementation of accrual-based government accounting standards which aims to create better financial reporting, as accrual GAS actually shows and presents the true financial condition of financial reporting, since transactions recorded on an accrual basis are based on their incidence, not on a cash/ cash equivalent obtained. This is in line with research conducted by Jamal and Tan (2010) who examine the impact of principles-based versus rule-based on reporting assessments 
of financial managers with three different types of auditors.

Thus, the characteristics of reliability in financial reporting can be met. This hypothesis is supported by some previous researches such as Diawati (2015), Inapty and Martiningsih (2016) also Adhi \& Suhardjo(2013). This is also in line with the statement of McCarthy, (2012) who states that the quality of financial statements will increase if it contains financial information that can be used for decision making by users of the financial statements concerned.

$\mathrm{H}_{1}$ : Accrual Based Government Accounting Standard has a positive effect on the Reliability of Financial Reporting

The implementation of accruals GAS also supports the creation of a good human resource capacity, as accrual GAS gives demands to ASN to be more skilled, especially in the implementation of an accrual accounting basis. Some previous studies such as Warsino in Winidyaningrum, (2009), Surepno (2015) as well as Sari \& Witono, (2014) also assume that human resources are the key to the implementation of accruals GAS. Accrual GAS also forces ASN to learn accrual accounting basis for the creation of financial reporting reliability. If there is Accrual GAS as a new policy then ASN capacity will increase as ASN will learn more about accounting basis, previously ASN can only use cash basis or cash basis to accrual, now ASN can develop its skills on an accrual basis. This is in accordance with the regulation which sets the State Civil Apparatus on Law Number 5 Year 2014 that human resources as ASN have the function of implementing public policy, the duty as the executor of public policy made by the Staff Officers in accordance with the provisions of legislation and also has a role as executor and supervisor of the government general duties implementation.

$\mathrm{H}_{2}$ : Accrual Based Government Accounting Standards have a positive effect on Human Resource Capacity

The output of local government accounting is the financial statements local government, and who makes the financial statements are human resources within the scope of the related SKPD. If the human resources in charge of managing the accounting system until reporting the financial statements of local government have a good/ adequate capacity, then the financial statements of local government will also be good too. A good Local Government Financial Statement is characterized by meeting the qualitative characteristics of financial reporting that is reliability. Supported by some previous research by Sirantiani \& Handayani Surastiani \& Handayani, (2015), Sari \& Witono, (2014), Setiawati \& Permata Sari, (2014), Widyaningrum and Rahmawati (2010) as well as Sukirman et al (2011), they find that human resources has a positive effect on the reliability of local government financial reporting. In line with that stated by Oluwatoyin, (2014); Savino, McGuire, \& White, (2012); Wüstemann \& Wüstemann, (2010) that human resource skills will increase along with the demands of technical complexity of modern business. Based on the regulation which sets about State Civil Apparatus Law Number 5 Year 2014, the third hypothesis is proposed in this research.

$\mathrm{H}_{3}$ : Human Resource Capacity positively affects the reliability of Financial Reporting

The fourth concept of this research is to know the effect of Accrual GAS on the reliability of financial reporting by determined its influence by human resource capacities in accordance with regulation theory, in which regulation theory presents several regulations related to the relationship between the three variables such as Government Regulation no. 71 Year 2010 on Accrual Based Government Accounting Standards, the Regulation of the Minister of Home Affairs (Permendagri) No. 64 of 2013 on the Implementation of Accrual-Based Government Accounting Standards at Local Government and Law no. 5 Year 2014 on State Civil Apparatus. Rules are binding and compelling for whom it is governed so as to cause an obligation to comply with the rules. If it is not adhered to, it can be ensured that the related agencies will get punishment / sanction so as to make them have to do something to meet the existing provisions. Reinforcement theory explains that one's behaviour can change if given strengthening or stimulus, stimulus in this case is a sanction if Accrual GAS is not applied well so make the employees in government agency will take action in the form of training or other action to increase self capacity to be able 
to process accountant recordings become accrual based financial statements in accordance with the standards.

The regulatory theory has the goal to require human resources as an ASN to be able to execute every policy given by the government. Reinforcement theory has explained how the required Accrual GAS will force ASN to increase their capacity so that the Accrual GAS is expected to affect the human resource capacity. HR capacity is known to have a positive effect on the reliability of financial reporting such as research conducted by Surastiani \& Handayani, (2015), Sari \& Witono, (2014), Winidyaningrum, (2009) as well as Sukirman et al (2011).

$\mathrm{H}_{4}$ : Human Resource Capacity mediates the influence between Accrual Based Government Accounting Standards on Financial Reporting Reliability

\section{METHOD}

This study uses a quantitative approach. The form of data in this study is primary data. There are 10 employees of accounting department and 52 General Treasurer of Expenditure in 52 SKPD in Kudus District which will be examined in this research. The 62 respondents have the same roles, functions and opportunities as research objects. Therefore, the entire population in this study will be used as a unit of analysis, so this study is a population study.

Table 1. Operationalization of Research Variables

\begin{tabular}{|c|c|c|}
\hline Variables & Definition & Measurement/Indicators \\
\hline $\begin{array}{l}\text { Reliability } \\
\text { of Financial } \\
\text { Reporting }\end{array}$ & $\begin{array}{l}\text { the ability of informa- } \\
\text { tion in the financial } \\
\text { statements are free from } \\
\text { misleading notions and } \\
\text { material errors, present- } \\
\text { ing every fact honestly } \\
\text { and can be verified }\end{array}$ & $\begin{array}{l}\text { 1. The existence of honest and reasonable financial } \\
\text { transactions } \\
\text { 2. The existence of the principal financial statements } \\
\text { according to the rules } \\
\text { 3. Information in the financial statements can be } \\
\text { tested } \\
\text { 4. There is a periodic reconciliation. } \\
\text { 5. Information can be utilized for general needs }\end{array}$ \\
\hline $\begin{array}{l}\text { Accrual } \\
\text { Based Gov- } \\
\text { ernment } \\
\text { Accounting } \\
\text { Standards } \\
\text { (Accrual } \\
\text { GAS) }\end{array}$ & $\begin{array}{l}\text { the accounting principles } \\
\text { applied in preparing and } \\
\text { presenting the govern- } \\
\text { ment financial state- } \\
\text { ments that acknowledge } \\
\text { transactions / events in } \\
\text { accordance with their } \\
\text { occurrence not when the } \\
\text { transaction is paid or } \\
\text { received. }\end{array}$ & $\begin{array}{l}\text { Acknowledgement : } \\
\text { LO Income } \\
\text { Obligation } \\
\text { Asset } \\
\text { Expense } \\
\text { Equity }\end{array}$ \\
\hline
\end{tabular}




\begin{tabular}{|c|c|c|}
\hline Variables & Definition & Measurement/Indicators \\
\hline $\begin{array}{l}\text { Human } \\
\text { Research } \\
\text { Capacity }\end{array}$ & $\begin{array}{l}\text { the ability of the state } \\
\text { civil apparatus either in } \\
\text { the level of individual } \\
\text { or group to carry out its } \\
\text { duties, functions and } \\
\text { authorities that have } \\
\text { been determined by the } \\
\text { government to achieve } \\
\text { the objectives effectively } \\
\text { and efficiently. }\end{array}$ & $\begin{array}{l}\text { The financial / accounting sub-section has sufficient } \\
\text { qualified staff. } \\
\text { At least } 10 \text { per cent of the staff of the financial / ac- } \\
\text { counting sub-section is a graduate of D3 accounting } \\
\text { or higher. } \\
\text { The financial / accounting sub-section has a clear } \\
\text { description of the role and function. } \\
\text { The roles and responsibilities of all officers of the } \\
\text { financial/ accounting subsection are clearly defined } \\
\text { in local regulations. } \\
\text { Tasks description of financial / accounting sub- } \\
\text { section is in accordance with the actual accounting } \\
\text { function. } \\
\text { There are guidelines regarding the accounting proce- } \\
\text { dures and process. } \\
\text { The financial / accounting subsection has performed } \\
\text { the accounting process. } \\
\text { The financial / accounting subsection has sufficient } \\
\text { operational supporting resources. } \\
\text { Trainings to assist mastery and skills development in } \\
\text { the tasks performed. } \\
\text { Funds are budgeted for the resources, equipment, } \\
\text { training required. }\end{array}$ \\
\hline
\end{tabular}

Taking is done by distributing a one to five-point questionnaire to accounting staff of the Regional Revenue, Finance and Asset Management Board (BPPKAD) and the general expenditure treasurer of SKPD under the auspices of BPPKAD in Kudus District. Testing of research instrument will use validity test and reliability test. Respondent information from the results of research instruments is also described using descriptive statistics. The hypothesis testing techniques used in this study are Inferential Statistics Techniques including Classical Assumption Test (Normality Test, Multicollinearity Test, Heteroscedasticity Test and Path Analysis (Analysis Path) with IBM SPSS 21 analysis tool.

\section{RESULTS AND DISCUSSIONS}

The questionnaires were distributed as many as 62 in accordance with the number of population, whereas the returned and processed questionnaires were only 52 questionnaires. The group of expenditure treasurer was 43 questionnaires and accounting personnel was 9 questionnaires. Testing the research instrument using the validity test and reliability test and test tool used was IBM SPSS 21. The result of validity test for each variable indicated the instrument in this study valid. Reliability Test in this study was seen using Cronbach Alpha value, and the three variables in this study showed Cronbach Alpha value more than 0.07. Nunnally (1994) in Ghozali, (2013) stated that the value was reliable.

Table 2 showed the number of respondents $(\mathrm{N})$ was 43 . The average answer for variable of financial reporting reliability was 44 , variable of accrual based government accounting standard was 37 and variable of human resource was 33 . When compared with the standard deviation value for each variable, all the average values were much larger than the standard deviation value. This comparison meant that the average value could be used as a representation of the overall data and the data was heterogeneous. 
Table 2. Descriptive Statistics

\begin{tabular}{lccccc}
\hline & $N$ & \multicolumn{2}{c}{ Mean } & Std. Deviation & Variance \\
\cline { 2 - 6 } & Statistic & Statistic & Std. Error & Statistic & Statistic \\
\hline FRR & 43 & 44.6977 & 0.64144 & 4.20620 & 17.692 \\
GAS & 43 & 37.3488 & 0.66546 & 4.36372 & 19.042 \\
HR & 43 & 33.7442 & 0.61819 & 4.05376 & 16.433 \\
\hline \multicolumn{5}{l}{ Source: } & The Result of Data Processing using IBM SPSS 21.0 (2017)
\end{tabular}

Classical assumption test in this study also gave a good result. Normality test resulted in normally distributed data. The result of multicollinearity test with Tolerance and Variance Inflation Factor (VIF) calculation indicated that there was no multicollinearity problem because VIF value was below 10 and tolerance value above 0.1 . Heteroscedasticity test in this study used Plot Graph, the result obtained that there was no heteroscedasticity in the regression model, so that the regression model is suitable to predict the reliability of financial reporting.

\section{Path Analysis}

The result of path analysis test was presented in Table 3 and Figure 1 to show the value of each of the effects resulted.

Table 3. The Result of Path Analysis Test

\begin{tabular}{lcccccc}
\hline \multirow{2}{*}{$\begin{array}{l}\text { Model } \\
B\end{array}$} & \multicolumn{2}{l}{$\begin{array}{l}\text { Unstandardized } \\
\text { Coefficients }\end{array}$} & $\begin{array}{c}\text { Standardized } \\
\text { Coefficients }\end{array}$ & \multirow{2}{*}{ S } & Sig. \\
\cline { 2 - 4 } & Std. Error & Beta & & & \\
\hline $\begin{array}{l}\text { Path Analy- } \\
\text { sis Test } 1\end{array}$ & & & & & & \\
(Constant) & 7.927 & 3.644 & & 2.175 & 0.035 \\
SAP & 0.691 & 0.097 & 0.744 & 7.132 & 0.000
\end{tabular}

a. Dependent Variable: HR

Path Anal-

ysis Test 2

$\begin{array}{lccccc}\text { (Constant) } & 16.607 & 4.061 & & 4.090 & 0.000 \\ \text { GAS } & 0.326 & 0.153 & 0.339 & 2.132 & 0.039 \\ \text { HR } & 0.471 & 0.165 & 0.454 & 2.860 & 0.007\end{array}$

a. Dependent Variable: FRR

Source : The Result of Data Processing with IBM SPSS 21.0 (2017)

The value of standarized beta coefficient (Model 1) for GAS was 0.691 (p2) and significant to 0,000 which meant GAS affected HR. The second test gave the value of standarized beta coefficient for GAS was 0.326 (p1) and significant to 0,000 meaning that GAS affected FRR. Second, the value of standarized beta coefficient for human resources was 0.471 (p3) and significant to 0,000 , which meant that HR affected FRR. Then, these three values could be directly incorporated into existing research models: 


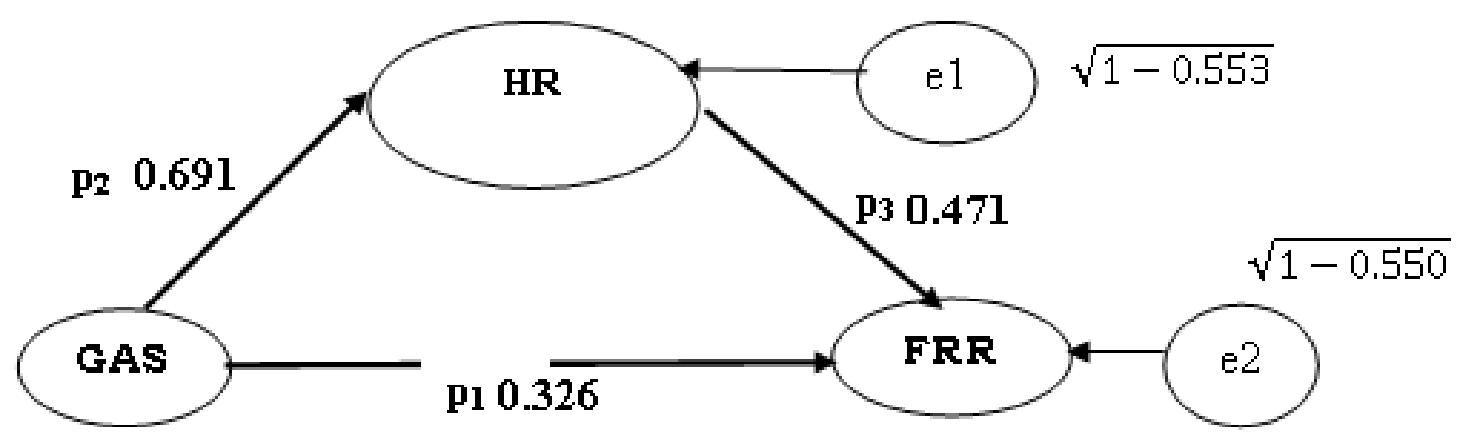

Figure 1. The Result of Multiple Regression Combination Path Analysis

\section{Coefficient of Determination Test $\left(\mathbf{R}^{2}\right)$ and Simultaneous Test}

The amount of adjusted $\mathrm{R}^{2}$ was 0.543 , this meant that $54.3 \%$ of $\mathrm{HR}$ variation could be explained by Accrual GAS variation and $\mathrm{R}^{2}$ would give value to $\mathrm{e}=$. The second relationship examined with $\mathrm{R}^{2}$ was the relationship between financial reporting reliability (FRR) as dependent with HR and GAS as independent variables. The result of SPSS model summary showed the amount of adjusted $\mathrm{R}^{2}$ was 0.527 , this meant that $52.7 \%$ of FRR variation could be explained by GAS and $H R$ variations and $\mathrm{R}^{2}$ would give value to $\mathrm{e} 2=$. In addition to the results of the summary model, a simultaneous significance test would also be displayed that would support the coefficient test.

The simultaneous test yielded F count value (Model 1) of 50.864 with a probability of 0.000 . Because the probability was much less than 0.05 , then regression could be used to predict human resources or it could be said that GAS had a significant effect to human resources. Coefficient of determination test and simultaneous test in essence to give result that GAS had an effect on human resources, the influence of which could be determined that was $54.3 \%$. Simultaneous test produced $\mathrm{F}$ count value (Model 2) equal to 24.864 with probability of 0.000 . Because the probability was much less than 0.05 , then regression could be used to predict FRR or it could be said that GAS and HR had an effect on FRR.

\section{Sobel Test}

$$
\begin{gathered}
S p 2 p 3=\sqrt{p 3^{2} S_{p 2}^{2}+p 2^{2} S_{p 3}^{2}+S_{p 2}^{2} S_{p 3}^{2}} \\
S p 2 p 3=\sqrt{(0.471)^{2}(0.97)^{2}+(0.691)^{2}(0.165)^{2}+(0.97)^{2}}(0.165)^{2} \\
S p 2 p 3=\sqrt{(0.221)(0.94)+(0.477)(0.027)+(0.94)(0.027)} \\
S p 2 p 3=\sqrt{0.456+0.114+0.16} \\
S p 2 p 3=\sqrt{0.730} \\
S p 2 p 3=0.852
\end{gathered}
$$

The calculation of sobel test resulted in $\mathrm{Sp} 2 \mathrm{p} 3=0.852$ but the result could not be used to determine whether the mediating variable in this study really can mediate the influence between dependent to independent or not, therefore the last test that was $t$ test conducted. 


\section{T Stastical Test}

$$
t \text { count }=\frac{p 2 p 3}{S p 2 p 3}=\frac{0.325461}{0.854}=0.3811
$$

$t$ count value of 0.3811 was smaller than $t$ table (2.021) with a significance level of 0.05 , it could be concluded that the mediating variables in this study did not mediate the influence between independent variables to dependent.

Table 4. Recapitulation of Hypothesis Test Result

\begin{tabular}{clcc}
\hline Hypothesis & Statements & $\mathrm{t}$ count $>\mathrm{t}$ table & Results \\
\hline $\mathrm{H}_{1}$ & $\begin{array}{l}\text { Accrual Based Government Accounting Standards } \\
\text { had a positive effect on the Reliability of Financial } \\
\text { Reporting }\end{array}$ & $2.43>1.68$ & Accepted \\
$\mathrm{H}_{2}$ & $\begin{array}{l}\text { Accrual Based Government Accounting Standards } \\
\text { had a positive effect on Human Resource Capacity }\end{array}$ & $2.86>1.68$ & Accepted \\
$\mathrm{H}_{3}$ & $\begin{array}{l}\text { Human Resource Capacity positively affected on } \\
\text { the reliability of Financial Reporting }\end{array}$ & $7.132>1.68$ & Accepted \\
$\mathrm{H}_{4}$ & $\begin{array}{l}\text { Human Resource Capacity Mediated the Effect } \\
\text { between Accrual-Based Government Accounting } \\
\text { Standards on Financial Reporting Reliability. }\end{array}$ & $0.381<2.021$ & Rejected \\
\hline
\end{tabular}

\section{Accrual Based Government Accounting Standards had a positive effect on the Reliability of Financial Reporting}

This research succeeded to prove the effect of accrual based government accountancy standard to the reliability of financial reporting in Kudus District. Accrual based government accounting standards have been applied in Kudus District since the issuance of GR no. 71 year 2010. Financial officers in the field of BPPKAD accounting and general expenditure treasurer of each SKPD could already run Accrual GAS well, so it could support the creation of financial reporting reliability. Benefits of Accrual GAS implementation was closely related to produce more real financial statements, related to the identification of financial statements and funding by the government. Since the implementation of Accrual GASs in Kudus District has been in accordance with the rules, then financial statements resulted became reliable. The implementation based on government regulations was one of the right approaches because Indonesia was still a developing country and developing countries needed a special approach (Tickell, 2010). Accrual GAS could minimize material errors because basically all the transactions recorded were based on their incidence, not when the cash was obtained. Besides, in Kudus District also conducted a periodic reconciliation, which was quarterly, per six months and annually, to minimize the balance difference in SKPD and PPKD. The theory of regulation also stated that it was needed certain rules or conditions in an accounting process. Provision is required for all parties both users and presenters to get the same and balanced information. This understanding could be directly correlated with the relationship between accrual -based government accounting system to the reliability of financial reporting. In accordance with GR. 71 Year 2010 stated that the financial statements resulting from the implementation of Accrual GAS was intended to provide better benefits for stakeholders, both users and government financial statement auditors, compared with the cost incurred. This was in line with one accounting principle that costs incurred in proportion to the benefits obtained. As described earlier, in this study Accrual GASs was proved could support the reliability of financial reporting in the Kudus District. Surepno, (2015) also revealed that the implementation of Accrual GAS was one of the government's policies in an effort to improve the quality of financial management. In addition, research conducted by Tikk, 2010), Diawati (2015), Inapty and Martiningsih (2016) has also proven that Accrual GASs affected the 
reliability of financial reporting.

\section{Accrual Based Government Accounting Standards had a positive effect on Human Resource Capacity}

The results of this study proved the influence of accrual-based government accounting standards on human resource capacity in Kudus district. Accrual-based government accounting standards contained some rules and guidelines in the preparation of accrual-based financial statements that must be known by ASN who served as treasurer or accounting officer, so ASN could better understand the implementation of Accrual GAS. The expenditure treasurer of the SKPD appointed as the respondent also revealed that the socialization related to the implementation of Accrual GAS has also been done in 2016 in the scope of the local government in Kudus District. The socialization was felt very useful in carrying out their duties as expenditure treasurer. It was another case with the accounting staff in BPPKAD, as an ASN in charge of making financial statements of Accrual GAS training consolidation which was obtained even more than the expenditure treasurer. The training was held in 2016 by the district government of Kudus district, year and 2016 by the provincial government, and year 2015 by the central government, but some BPPKAD accounting officials argued that in 2017 it was deemed necessary to conduct Accrual GASs training again because there were many ASN mutations who was in charge of as expenditure treasurer of SKPD. If it was correlated with the theory of regulation then, there were demands stated in Accrual GAS (GR No. 71 of 2010) and Law no. 5 Year 2014 on the State Civil Apparatus that described the roles, duties and functions of human resources as an ASN, in which ASN should strive to implement each policy that has been set by the government as much as possible. So the capacity of human resources which was more skilled in the implementation of accrual base could be realized.

\section{Human Resource Capacity positively affected the reliability of Financial Reporting}

This research has proven the influence of human resource capacity on the reliability of financial reporting in Kudus District. The capacity of human resources in Kudus District has met the indicators of GTZ and USAID / CLEAN Urban 2001, which have been used in the previous studies on human resource capacity. The most obvious evidence obtained from this research questionnaire was related to the educational background owned by ASN who served as an accounting officer of BPPKAD. Seven of the 9 ASN had backgrounds of accounting education. This meant that as a person who served in the scope of BPPKAD, the ASN has already meet the qualification to carry out government accounting activities so as to create the reliability of financial reporting. The output of local government accounting was the local government financial statements, and who made the financial statements were human resources that existed within the scope of SKPD, so that this research was in line with the regulation theory as stated in Law no. 5 year 2014 on State Civil Apparatus. The results of this study were supported by research conducted by Winidyaningrum, (2009), Sari \& Witono, (2014) Sukirman et al (2011) also the research conducted by Desmiyawati (2014) which mentioned that the source of human resources was potentially positive for the reliability of local government financial reporting.

\section{Human Resource Capacity mediated the influence between Accrual Based Government Accounting Standards on Financial Reporting Reliability}

The results of this study did not succeed to prove the influence of mediation given by human resource capacity to the relationship between accrual based government accounting standards and the reliability of financial reporting in the scope of government of Kudus District. This meant that the human resource capacity in Kudus district did not affect the implementation of Accrual GAS to create financial reporting reliability, since basically GAS Accrual itself has been strong enough to create the reliability of financial reporting as listed in the first hypothesis. So if there was no human resource capacity variable which would mediate it would not be a problem. Human 
resource capacity was a key factor in the implementation of Accrual GAS, but from the results of the descriptive statistical analysis in Table 2, it was the human resource capacity variable that has the lowest value among independent and dependent variables. This was the reason why human resource capacity variable could not mediate the influence between Accrual GAS on Financial Reporting Reliability. This result did not support the theory of regulation. Regulatory theories expected results in accordance with the legislation which was stated in the GR. 71 of 2010 and Law no. 5 Year 2014. As explained earlier that the implementation of Accrual GAS was used to support the reliability of financial reporting, but the influence was determined by the existence of human resource capacity variable.

In accordance with the originality of this study, placing human resources as mediating variable was something new but, if it was viewed on the relationships between the variables individually all had a positive effect, thus raising the final concept of placing the capacity of human resources as a mediating variable. Additionally, placing the human resources variable as a mediating variable was not without reasons, some of the earlier studies gave researchers the opportunity to place the variable of human resource capacity as a mediating variable. It could be seen that accrual-based government accounting standards had a significant positive effect on the capacity of human resources, and the capacity of human resources positively affected the reliability of financial reporting, so it could be argued that human resource capacity was in the midst of the influence between Accrual GAS and financial reporting reliability. That was which underlying why the capacity of human resources was placed as a mediating variable.

\section{CONCLUSIONS}

The results of the data analysis show that accrual-based government accounting standards and human resource capacity have a positive effect on the reliability of financial reporting, in addition to accrual-based government accounting standards also has a positive effect on human resource capacity. The results of data analysis indicate that there is no influence of mediation by human resource capacity on the relationship between accrual based government accounting standards on the reliability of financial reporting. The results of this study can be understood that to improve the reliability of financial reporting should apply Accrual GAS and human resource capacity should be improved although not able to mediate the effect of GAS on the reliability of financial reporting, but directly the capacity of human resources capable of affecting the reliability of financial reporting.

Suggestions for Kudus District Government should be able to conduct training related to the implementation of Accrual Based Government Accounting Standards, but it is also expected to recruit State Civil Apparatus in accordance with their competence, if serving as treasurer of expenditure, the competence is accounting. Further research is expected to use other objects / districts or expand the research area so that the resulting data becomes more relevant and also add other variables that may affect the reliability of financial reporting.

\section{REFERENCES}

Adhi, D. K., \& Suhardjo, Y. (2013). Pengaruh Penerapan Standar Akuntansi Pemerintahan dan Kualitas Aparatur Pemerintah Daerah terhadap kualitas laporan keuangan (studi kasus pada pemerintah kota Tual). Jurnal STIE Semarang, 5(3), 93-111.

Anggraeni, D. T. (2015). Faktor-Faktor yang Mempengaruhi Keterandalan Pelaporan Keuangan Pemerintah Daerah (Studi pada SKPD di Kabupaten Sidoarjo). Jurnal Ilmu Dan Riset Akuntansi, 3(3).

Desmiyawati. 2014. Faktor-Faktor Yang Mempengaruhi Keandalan Dan Ketepatan Waktu Pelaporan Keuangan (Study EmpirisPada SKPD Pemda Riau). Jurnal Akuntansi, 2 (1) 163-178

Diawati, M. (2015). Faktor - Faktor Yang Mempengaruhi Keterandalan Laporan Keuangan Daerah Pemerintahan Kota Surakarta. Skripsi. Dipublikasikan Surakarta :Universitas Muhamadiyah Surakarta 
Ghozali, I. (2013). Aplikasi Analisis Multivariate Lanjutan dengan Program IBM SPSS 21. Edisi.

Inapty, M. A. F. B., Martiningsih, S. P. 2016. Pengaruh Penerapan Standar Akuntansi Pemerintah, Kompetensi Aparatur Dan Peran Audit Internal Terhadap Kualitas Informasi Laporan Keuangan. Akuntabilitas: Jurnal Ilmu Akuntansi, 9 (1) 27-42

Jamal, K., \& Tan, H. 2010. Joint effects of principles-based versus rules-based standards and auditor type in constraining financial managers' aggressive reporting. The Accounting Review, 85(4), 1325-1346

Kementrian Keuangan Republik Indonesia. 2014. Modul Akuntansi Keuangan Pemerintah Daerah dan SKPD. Direktorat Jendral Perimbangan Keuangan

McCarthy, M. (2012). Financial statement preparers' revenue decisions: Accuracy in applying rules-based standards and the IASB-FASB revenue recognition model. Nova Southeastern University.

Noviyanti, N.A., Kiswanto. 2016. Pengaruh Karakteristik Pemerintah Daerah, Temuan Audit Bpk terhadap Kinerja Keuangan Pemerintah Daerah. Accounting Analysis Journal, 5 (1)

Oluwatoyin, A. S. (2014). Human Resources Accounting and Disclosure in Financial Statement: Literature Review. Human Resources, 5(22).

Pemerintah Daerah Kabupaten Kudus. 2016. https://dppkd-kabkudus.com/ (Diunduh tanggal 9 Januari 2017)

Republik Indonesia, Peraturan Menteri Dalam Negeri Nomor 64 Tahun 2013 tentang Penerapan Standar Akuntansi Pemerintahan Berbasis Akrual pada Pemerintah Daerah

Republik Indonesia, Peraturan Pemerintah Nomor 71 Tahun 2010 tentang Standar Akuntansi Pemerintahan

Robins, S. P., \& Judge, T. A. (2007). Perilaku organisasi, Buku 1 edisi 12. Terjemahan Diana Angelica). Jakarta: Salemba Empat.

Sari, S. P., \& Witono, B. (2014). Keterandalan dan ketepatwaktuan pelaporan keuangan daerah ditinjau dari sumber daya manusia, pengendalian internal dan pemanfaatan teknologi informasi.

Savino, D. M., McGuire, K. S., \& White, K. M. (2012). Human asset measurement: A comparison of the artifact-based approach versus input methods. Journal of Management Policy and Practice, 13(1), 39.

Setiawati, E., \& Permata Sari, S. (2014). Kualitas Pelaporan Keuangan Pemerintah Daerah Ditinjau Dari Sumber Daya Manusia, Pengendalian Intern, Pemanfaatan Teknologi Informasi dan Pemahaman Akuntansi (Studi Empiris Pada Pemerintah Kabupaten dan Kota di Wilayah Eks Karesidenan Surakarta).

Setiawati, E., S.P. Sari. 2014. Kualitas Pelaporan Keuangan Pemerintah Daerah Ditinjau dari Sumber Daya Manusia, Pengendalian Intern, Pemanfaatan Teknologi Informasi dan Pemahaman Akuntansi. Seminar Nasional Dan Call For Paper Program Studi Akuntansi-FEB UMS, 418-425

Stigler, G. J. (1971). The Theory of Economic Regulation. The Bell Journal of Economics and Management Science, 2 (1), 3-21. Stigler 32 Bell Journal of Economics and Management Science1971.

Surastiani, D. P., \& Handayani, B. D. (2015). Analisis Faktor-Faktor Yang Mempengaruhi Kualitas Informasi Laporan Keuangan Pemerintah Daerah. Jurnal Dinamika Akuntansi, 7(2).

Surepno, S. (2015). Kunci Sukses dan Peran Strategis Implementasi Akuntansi Berbasis Akrual. Jurnal Dinamika Akuntansi, 7(2).

Sukirman, S., Havid, E. S. Nugraheni. 2011. Faktor-Faktor yang Mempengaruhi Keterandalan dan Ketepatwaktuan Pelaporan Keuangan dengn Pengendalian Intern Akuntansi sebagai Variabel Pemoderasi (Studi Empiris pada Pemerintah Daerah Kabupaten. Sustainable Competitive Advantage (SCA), 3 (1)

Surastiani, D. P., B. D. Handayani. 2015. Analisis Faktor-Faktor yang Mempengaruhi Kualitas Informasi Laporan Keuangan Pemerintah Daerah. Jurnal Dinamika Akuntansi, 7 (2) 139-149

Tickell, G. (2010). Cash to accrual accounting: One nation's dilemma. The International Business \& Economics Research Journal, 9 (11), 71Tikk, J. (2010). Accounting changes in the public sector in Estonia. Business: Theory and Practice, 11(1), 77-85.

Utami, S. S. (2012). Pengaruh Kepemimpinan, Motivasi, Komunikasi Dan Lingkungan Kerja Terhadap Kinerja Pegawai Kecamatan Jumantono Kabupaten Karanganyar. Manajemen Sumber Daya Manusia, 4(1).

Wahyuni, D. U. (2008). Pengaruh Motivasi, Persepsi dan Sikap Konsumen terhadap Keputusan Pembelian Sepeda Motor Merek“ Honda” Di Kawasan Surabaya Barat. Jurnal Manajemen Dan Kewirausahaan, $10(1), \mathrm{pp}-30$.

Widyastuti, N. M. A., Sujana, E. Adiputra, M. P. (2015). Analisis Kesiapan Pemerintah Daerah dalam Menerapkan Standar Akuntansi Pemerintahan Berbasis Akrual di Kabupaten Gianyar. JIMAT (Jurnal Ilmiah Mahasiswa Akuntansi S1), 3(1) 
Winidyaningrum, C. (2009). Pengaruh Sumber Daya Manusia Dan Pemanfaatan Teknologi Informasi Terhadap Keterandalan Dan Ketepatwaktuan Pelaporan Keuangan Pemerintah Daerah Dengan Variabel Intervening Pengendalian Intern Akuntansi (Studi Empiris di Pemda subosukawonosraten). Universitas Sebelas Maret.

Wüstemann, J., \& Wüstemann, S. (2010). Why Consistency of Accounting Standards Matters: A Contribution to the Rules-Versus-Principles Debate in Financial Reporting. Abacus, 46(1), 1-27. 